5

\title{
One Message Leading to Another
}

\author{
John Berger ${ }^{+}$ \\ † The author has passed away. \\ Academic Editor: Annabel Martín \\ Received: 15 February 2017; Accepted: 19 May 2017; Published: 26 May 2017
}

The wonderful American poet, Adrienne Rich, pointed out in a recent lecture that: "This year a report from the Bureau of Justice Statistics finds that 1 out of every 136 residents of the United States is behind bars-many in jails, unconvicted."

In the same lecture she quoted the Greek poet, Yannis Ritsos:

In the field the last swallow had lingered late,

balancing in the air like a black ribbon on the sleeve of autumn

Nothing else remained. Only the burned houses smouldering still.

You just phoned and immediately I knew it was an unexpected call from you, speaking from your flat in in the Via Paolo Sarpi. (Two days after the election results and Berlusconi's comeback.) The speed with which we identify a familiar voice coming out of the blue, is comforting, but also somewhat mysterious. Because the measures, the units, we use in calculating the clear distinction that exists between one voice and another, are unformulated and nameless. They don't have a code. These days more and more is encoded.

So I wonder whether there aren't other measures, equally uncoded yet precise, with which we calculate other givens.

For example, the amount of circumstantial freedom existing in a given situation, its extent and its strict limits. Prisoners become experts about this. They develop a particular sensitivity towards liberty, not as a principle, but as a granular substance. They spot almost immediately, fragments of liberty whenever they occur.

On an ordinary day, when nothing is happening and the crises announced hourly are the old familiar ones-and the politicians are presenting themselves as the only possible alternative to CATASTROPHE-people as they pass one another, exchange glances to check whether others are envisaging the same thing when they say to themselves: So this is life!

Often they are envisaging the same thing and in this instant of sharing there is a kind of solidarity before anything further has been said or discussed.

I'm searching for words to describe the period of history we're living. To say it's unprecedented means little because all periods were unprecedented since History was first discovered!

I'm not searching for a complex definition of the period we are living through — there are a number of thinkers, such as Zygmunt Bauman who have taken on this essential task. I'm looking for nothing more than a figurative image to serve as a landmark. Landmarks don't fully explain themselves, but they offer a reference point which can be shared. In this they are like the tacit assumptions contained in popular proverbs. Without landmarks there is the great human risk of turning in circles.

The landmark I've found is that of prison. Nothing less. Across the planet we are living in a prison. 
The word we, when printed or pronounced on screens, has become suspect, for it's continually used by those with power in the demagogic claim that they are also speaking for those who are denied power. Let's talk of ourselves as they. They are living in a prison.

What kind of prison? How is it constructed? Where is it situated? Or am I only using the word as a figure of speech?

No, it's not a metaphor, the imprisonment is real, but to describe it one has to think historically.

What kind of prison?

Michel Foucault has graphically shown how the penitentiary was a late eighteenth, early nineteenth century invention, closely linked to industrial production and its factories and its utilitarian philosophy. Earlier, there were jails which were extensions of the cage and the dungeon. What distinguishes the penitentiary is the number of prisoners it can pack in, and the fact that all of them are under continuous surveillance - thanks to the model of the Panoptician, as conceived by Jeremy Bentham, who introduced the principle of accountancy into ethics.

Accountancy demands that every transaction be noted. Hence the penitentiaries circular walls, the cells arranged in circles and the screw's watchtower at the centre. Bentham, who was John Stuart Mill's tutor at the beginning of the 19th Century, was the principal utilitarian apologist for industrial capitalism.

Today in the era of globalisation, the world is dominated by financial, not industrial capital, and the dogmas defining criminality and the logics of imprisonment, have changed radically. Penitentiaries still exist and more and more are being built. But prison walls now serve a different purpose. What constitutes an incarceration area has been transformed.

Twenty-five years ago Nella Bielski and I wrote A Question of Geography, a play about the Goulag. In Act Two a Zek (political prisoner) talks to a boy who has just arrived, about choice, about the limits of what can be chosen in a labour camp.

When you drag yourself back after a day's work in the taïga, when you are marched back, half dead with fatigue and hunger, you are given your ration of soup and bread. About the soup you have no choice-it has to be eaten whilst it's hot, or whilst it's at least warm. About the $400 \mathrm{~g}$ of bread you have a choice. For instance, you can cut it into three little bits: one to eat now with the soup, one to suck in the mouth before going to sleep in your bunk, and the third to keep until next morning at ten, when you're working in the taïga and the emptiness in your stomach feels like a stone.

You empty a wheelbarrow full of rock. About pushing the barrow to the dump you have no choice. Now it's empty you have a choice. You can walk your barrow back just like you came, or-if you're clever, and survival makes you clever-you push it back like this, almost upright. If you choose the second way you give your shoulders a rest.

If you are a Zek and you become a team leader, you have the choice of playing at being a screw, or of never forgetting that you are a Zek.

The Goulag no longer exists. Millions work, however, under conditions which are not very different. What has changed is the forensic logic applied to workers and criminals.

During the Goulag political prisoners, categorised as criminals, were reduced to slave-labourers. Today millions of brutally exploited workers are being reduced to the status of criminals.

The Goulag Equation: criminal = slave labourer has been rewritten by neoliberalism to become: worker $=$ hidden criminal. The whole drama of global migration is expressed in this new formula: those who work are latent criminals. When accused, they are found guilty of trying at all costs to survive.

Fifteen million Mexican women and men work in the U.S. without papers and are consequently illegal. A concrete wall of $1200 \mathrm{~km}$ and a "virtual" wall of 1800 watch towers, are being planned along 
the frontier between the U.S. and Mexico. Ways around them though—all of them dangerous—will of course be found.

Between industrial capitalism-dependant on manufacture and factories, and financial capitalism-dependant upon free-market speculation and front office traders (Speculative financial transactions add up, each day, to 1300 billion dollars; 50 times more than the sum of commercial exchanges.) the incarceration area has changed.

The prison is now as large as the planet and its allotted zones vary and can be termed work-site, refugee-camp, shopping mall, periphery, ghetto, office block, favela, suburb. What is essential is that those incarcerated in these zones, are fellow prisoners.

It's the first week in May and on the hillsides and mountains, along the avenues and around the gates, in the northern hemisphere, the leaves of most of the trees are coming out. Not only are all their different varieties of green still distinct, people also have the impression that each single leaf is distinct, and so they are confronting billions (the word has been corrupted by dollars), not billions, they are confronting an infinite multitude of new leaves.

For prisoners, small visible signs of nature's continuity have always been, and still are, a covert encouragement.

Today the purpose of most prison walls (concrete, electronic, patrolled or interrogatory) is not to keep prisoners in and correct them, but to keep prisoners out and exclude them.

Most of the excluded are anonymous-hence the obsession of all security forces with identity. They are also numberless. For two reasons. First because their numbers fluctuate; every famine, natural disaster and military intervention (now called policing!) either diminishes or increases their multitude. And, secondly, because to assess their number is to confront the truth that they constitute most of those living on the surface of the earth - and to face this is to plummet into absolute absurdity.

Have you noticed-small commodities are increasingly difficult to remove from their packaging? Something similar has happened with the lives of the gainfully employed. Those who have legal employment and are not poor, are living in a very reduced space that allows them fewer and fewer choices-except the continual binary choice between obedience and disobedience. Their working hours, their place of residence, their past skills and experience, their health, the future of their children-everything outside their function as employees has to take a small second place beside the unforeseeable and vast demands of Liquid Profit. Furthermore, the Rigidity of this house-rule is called Flexibility. In prison words get turned upside down.

The alarming pressure of high-grade working conditions has recently obliged the courts in Japan to recognise and define a new coroner's category of "Death by Overwork".

No other system, the gainfully employed are told, is feasible. There is no alternative. Take the elevator. The elevator is as small as a cell.

"Les peuples n'ont jamais que le degré de liberté que leur audace conquiert sur la peur."

- Stendhal

I'm watching a five year old girl having a swimming lesson in a municipal indoor swimming pool. She's wearing a dark blue costume. She can swim and doesn't yet have the confidence to swim alone without any support. The instructor takes her to the deep end of the pool. The girl is going to jump into the water whilst grasping a long rod held out towards her by her teacher. It's a way of getting over her fear of water. They did the same thing yesterday. 
Today she wants the girl to jump without clutching the rod. One, two, three! The girl jumps but at the last moment seizes the rod. Not a word is spoken. A faint smile passes between the woman and the girl. The girl cheeky, the woman patient.

The girl clambers up the ladder out of the pool and returns to the edge. Let me jump again! She says. The woman nods. The girl inhales, hissing, and jumps, hands to her side, holding nothing. When she comes up to the surface, the tip of the rod is there in front of her very nose. She swims two strokes to the ladder without touching the rod. Bravo!

At the moment when the girl jumped without the rod, neither of them was in prison.

Look at the power structure of the unprecedented surrounding world, and how its authority functions. Every tyranny finds and improvises its own set of controls. Which is why they are often, at first, not recognised as the vicious controls they are.

The market forces dominating the world assert that they are inevitably stronger than any nation-state. The assertion is corroborated every minute. From an unsolicited telephone call trying to persuade the subscriber to take out a private health insurance or pension, to the latest ultimatum of the World Trade Organisation.

As a result, most governments no longer govern. A government no longer steers towards its own chosen destination. The word horizon, with its promise of a hoped-for future, has vanished from political discourse- on both right and left. All that remains for debate is how to measure what is there. Opinion polls replace direction and replace desire.

Most governments herd instead of steer. (In U.S. prison slang, herders is one of the many words for jailers.)

In the 18th Century long-term imprisonment was approvingly defined as a punishment of "civic death". Three centuries later, governments are imposing by law, force, economic threats and their buzz, mass regimes of "civic death".

Wasn't living under any tyranny in the past a form of imprisonment? Not in the sense I'm describing. What is being lived today is new, because of its relationship with space.

It's here that the thinking of Zygmunt Bauman is illuminating. He points out that the corporate market forces now running the world are ex-territorial, that's to say "free from territorial constraints the constraints of locality." They are perpetually remote, anonymous and thus never have to take account of the territorial, physical consequences of their actions. He quotes Hans Tietmeyer, president of the German Federal Bank: "Today's stake is to create conditions favourable to the confidence of investors". The single supreme priority.

Following this, the control of the world's populations, who consist of producers, consumers and the marginalised poor, is the task allotted to the obedient national governments.

The planet is a prison and the obedient governments, whether of right or left, are the herders.

The prison-system operates thanks to cyberspace. Cyberspace offers the market a speed of exchange, which is almost instantaneous, and which is used across the world day and night for trading. From this speed, from this velocity, the market tyranny gains its ex-territorial license. Such velocity, however, has a pathological effect on its practitioners; it anaesthetises them. No matter what has befallen, Business As Usual.

There is no place for pain in that velocity: announcements of pain perhaps, but not the suffering of it. Consequently, the human condition is banished, excluded, from those operating the system. The operators are alone because utterly heartless.

Earlier, tyrants were pitiless and inaccessible, but they were neighbours, who were subject to pain. This is no longer the case, and in the long term this will be the system's fatal flaw. 
The tall doors swing back

We're inside the prison yard

in a new season.

—Tomas Transtömer

They (we) are fellow-prisoners. That recognition, in whatever tone of voice it may be declared, contains a refusal. Nowhere more than in prison is the future calculated and awaited as something utterly opposed to the present. The incarcerated never accept the present as final.

Meanwhile, how to live this present? What conclusions to draw? What decisions to take? How to act? I have a few guidelines to suggest, now that the landmark has been established.

On this side of the walls experience is listened to, no experience is considered obsolete. Here survival is respected and it's a commonplace that survival frequently depends upon solidarity between fellow prisoners. The authorities know this-hence their use of solitary confinement, either through physical isolation or through their manipulative brainwashing, whereby individual lives are isolated from history, from heritage, from the earth, and, above all, from a common future.

Ignore the jailer's talk. There are of course bad jailers and less bad. In certain conditions it's useful to note the difference. But what they say-including the less evil ones-is bullshit. Their hymns, their shibboleths, their incanted words such as Security, Democracy, Identity, Civilisation, Flexibility, Productivity, Human Rights, Integration, Terrorism, Freedom, are repeated and repeated in order to confuse, divide, distract and sedate all fellow-prisoners. On this side of the walls, words spoken by the jailers are meaningless and are no longer useful for thought. They cut through nothing. Reject them even when thinking silently to oneself.

By contrast, prisoners have their own vocabulary with which they think. Many words are kept secret and many are local, with countless variations. Small words and phrases, small yet containing a world, such as: I'll-show-you-my-way, sometimes-wonder, pajarillo, somethings-happening-in-B-wing, stripped, take-this-small-earring, died-for-us, go-for-it, etc.

Between fellow-prisoners there are conflicts, sometimes violent. All prisoners are deprived, yet there are degrees of deprivation and the differences of degree provoke envy. On this side of the walls life is cheap. The very facelessness of the global tyranny encourages hunts to find scapegoats, to find instantly definable enemies among other prisoners. The asphyxiating cells then become a madhouse. The poor attack the poor, the invaded pillage the invaded. Fellow-prisoners should not be idealised.

Without idealisation, simply take note that what they have in common-which is their unnecessary suffering, their endurance, their cunning-is more significant, more telling, than what separates them. And from this, new forms of solidarity are being born. The new solidarities start with the mutual recognition of differences and multiplicity. So this is life! A solidarity, not of masses but of interconnectivity, far more appropriate to the conditions of prison life.

The authorities do their systematic best to keep fellow-prisoners misinformed about what is happening elsewhere in the world prison. They do not, in the aggressive sense of the term, indoctrinate. Indoctrination is reserved for the training of the small elite of traders and managerial and market experts. For the mass prison population the aim is not to activate them, but to keep them in a state of passive uncertainty, to remind them remorselessly that there is nothing in life but risk, and that the earth is an unsafe place.

This is done with carefully selected information, with misinformation, commentaries, rumours, fictions. Insofar as the operation succeeds, it proposes and maintains an hallucinating paradox, for it tricks a prison population into believing that the priority for each one of them is to make arrangements 
for their own personal protection and to acquire somehow, even though incarcerated, their own particular exemption from the common fate.

The image of mankind, as transmitted through this view of the world, is again, without precedent. Mankind is presented as a coward; only winners are brave. In addition, there are no gifts; there are only prizes.

Prisoners have always found ways of communicating with one another. In today's global prison cyberspace can be used against the interests of those who first installed it. Like this, prisoners inform themselves about what the world does each day, and they follow suppressed stories from the past and so stand shoulder to shoulder with the dead.

In doing so, they rediscover little gifts, examples of courage, a single rose in a kitchen where there's not enough to eat, indelible pains, the indefatigability of mothers, laughter, mutual aid, silence, ever-widening resistance, willing sacrifice, more laughter.

The messages are brief but they extend in the solitude of their (our) nights.

The final guideline is not tactical but strategic.

The fact that the world's tyrants are ex-territorial explains the extent of their overseeing power, yet it also indicates a coming weakness. They operate in cyberspace and they lodge in guarded condominiums. They have no knowledge of the surrounding earth. Furthermore, they dismiss such knowledge as superficial not profound. Only extracted resources count. They cannot listen to the earth. On the ground they are blind. In the local they are lost.

For fellow-prisoners the opposite is true. Cells have walls that touch across the world. Effective acts of sustained resistance will be embedded in the local, near and far. Outback resistance, listening to the earth.

Liberty is slowly being found not outside but in the depths of the prison.

Not only did I immediately recognise your voice, speaking from your flat in the Via Paolo Sarpi, I could also guess, thanks to your voice, how you were feeling. I sensed your exasperation or, rather, an exasperated endurance which was combined —and this is so typical of you —with the quick steps of our next hope.

\section{End}

Conflicts of Interest: The author declares no conflict of interest. 